\author{
초종 및 반전횟수가 봄철 일년생 콩과목초 건초의 품질에 \\ 미치는 영향 \\ 김종덕 · 권찬호 · 김호중 · 김명기 \\ 천안연암대학
}

\title{
Effect of Species and Tedding Frequency on the Quality of Annual Legume Hay in Spring
}

J. D. Kim, C. H. Kwon, H. J. Kim and M. G. Kim

Cheonan Yonam College

\begin{abstract}
No comprehensive forage quality of annual legumes harvested and cured in spring has been conducted in Korea. Therefore, this experiment was carried out to gain information on the quality of crimson clover (Trifolium incarnatum L.), bolta balansa clover(Trifolium balanansae L.), and persian clover(Trifolium resupinatum L.) during field curing in spring. The dry matter content of crimson clover at harvest was $24.7 \%$, while bolta balansa and persian clovers had 20.4 and 18.8\%, respectively. The moisture content of persian clover was low at the final curing day. But All species took 4 days to reach moisture content under $20 \%$. Tedding frequency did not affect moisture content, but consistent trends were also observed during the field curing. Persian clover tended to show a higher leaf-stem ratio than crimson and bolta balansa clovers on dry matter basis. Crude protein of persian clover(19.5\%) was higher than other legumes. The percentage of crude protein was decreased from 17.8 to $16.5 \%$ as tedding frequency often did. Neutral detergent fiber(NDF) and acid detergent fiber(ADF) contents of persian clover were lower than those of other legumes. From the comparison among tedding frequency, NDF and ADF contents of three times were higher than those of one and two times. Relative feed value(RFV) of persian clover hay was the highest(178) and classified as Grade Prime in forage quality standard. Crimson and bolta balansa clovers in the RFV were also high quality as Grade 1 in forage quality standard. The RFV of legume hay was decreased from 150 to 140 as tedding frequency often did. Results of the experiment indicate that hay quality of persian clover was higher than other clovers. And this is due to high leaf and stem content, hollow stem and late maturity stage. Then tedding frequency in annual legume can be teded by two times for quality.
\end{abstract}

(Key words : Crimson clover, Bolta balansa clover, Persian clover, Crude protein, Relative feed value)

$\begin{array}{cl}\text { I 서 론 } & \begin{array}{c}\text { 수입조사료의 사용량이 매년 증가하여 } 2003 \\ \text { 년 현재 600천톤으로 조사료 공급량의 } 15 \%\end{array} \\ \text { 최근 우리나라 낙농가들이 젖소의 대사질 } & \text { 를 차지하고 있다(이, 2003). 그러나 조사료 } \\ \text { 병, 발굽질병, 번식장애 감소와 젖소의 경제 } & \text { 수입쿼터에 의한 공급 부족으로 수입건초 가 } \\ \text { 수명 연장을 위해서는 조사료의 중요성을 인 } & \text { 격이 상승하여 사료비가 크게 증가하였다. } \\ \text { 식하여 조사료 사용량이 증가하였으며, 특히 } & \text { 따라서 낙농가의 우유생산비 중 가장 큰 비 }\end{array}$

Corresponding author : J. D. Kim, Cheonan Yonam College, Sunghwan, Cheonan-Si 330-802, Korea. Tel : 041-580-1088, Fax : 041-580-1249, E-mail : yasc@yonam.ac.kr 
중을 차지하는 사료비를 절감하기 위한 양질 의 자가 건초생산 기술의 보급이 시급하다고 할 수 있다.

일년생 콩과목초의 경우 밭에서는 옥수수 및 수단그라스와 논에서는 벼와 2모작이 가 능한 작물이다. 더욱이 콩과목초는 화본과에 비하여 반추가축에게 중요한 단백질 공급원 이자 근류균 생성에 의한 질소공급원이기 때 문에 지상부는 사료작물로 이용하고 지하부 는 녹비로 이용하는 것이 이용을 증대하는 방법이라고 할 수 있다(김 및 김, 1993 ; 김 등, 1997; 김 등, 2002).

양질의 건초를 조제하기 위해서는 좋은 날 씨와 작물의 수확적기가 가장 중요하다(서 등, 2001). 강우는 건물과 양분손실을 일으켜 건초의 품질을 저하시키는데(Smith 및 Brown, 1994) 콩과목초의 경우 잎의 손실이 1.9 8 배 많아지며(Collins, 1983), 이는 강우량 뿐만 아니라 강우빈도에 따라서도 차이가 발생한 다(Rotz 및 Abrams, 1987). 이러한 조건을 볼 때 우리나라에서 5월은 강우량이 적고 온도 가 상승하는 시기이며, 일년생 콩과목초의 수확적기에 해당한다.

일년생 콩과목초는 다년생 콩과목초에 비 하여 숙기가 빠르기 때문에 4월 말에서 5월 초에 수확이 가능하며, 특히 persian clover는 줄기가 비워있어 줄기와 잎의 건조속도가 비 슷하여 건초제조시 건조에 의한 잎의 손실이 적은 작물이다(김 등, 2002).

그러나 콩과목초로 건초를 만드는 것은 화 본과에 비하여 건조가 어렵고, 대부분 영양 분이 잎에 집중되어 있고, 기호성이 높은 잎 은 건조가 진행될수록 탈락되기 쉬우며, 실 제로 포장에서 건초 및 곤포 성형과정에서 많은 손실이 일어나고 있다(김 등, 1999).

일반적으로 수확직후 포장상태에서 건조속 도를 높이기 위해서는 mower conditioner이나 건조제를 사용하거나 수확후 반전을 많이 이 용하고 있다(서 등, 2001; 한 및 김, 1996). Pitt 등(1991)은 건초는 기상요인과 관리적인 측면에서의 수확시기, 집초나 반전이 건조율
에 영향을 미치는 주요인으로 들었다.

따라서 본 시험은 2모작 작부체계에 적합 한 일년생 콩과목초를 생산하여 조단백질 함 량이 높은 양질의 조사료를 공급하기 위하여 봄철에 건초로 제조하였을 때 건조 중에 일 어나는 품질의 변화를 구명하기 위하여 실시 하였다.

\section{ㅍ 재료 및 방법}

본 시험은 충남 성환의 천안연암대학 실습 농장에서 일년생 콩과목초를 2000년 9월 16 일에 파종하고, 월동후 이듬해에 5월 16일에 수확하여 건조하였다.

본 시험의 시험설계는 crimson clover(Trifolium incarnatum L.) 'Tibbee', bolta balansa clover (Trifolium balanansae All) 'Common', 및 persian clover(Trifolium resupinatum L.) 'Leeton' 의 초종을 주구, 반전횟수로 1 일 1 회, 2 회 및 3 회의 세구로 처리하여 비교시험을 실시하였다.

수확한 목초의 포장건조는 수확당일인 5월 16일부터 5월 23일까지 7일간 실시하였다. 콩과목초의 건조중 수분 함량 변화를 조사하 고자 통기성 및 광투과성이 좋은 $20 \mathrm{mesh}$ 의 양파망에 약 $1,000 \mathrm{~g}$ 을 포장건조 조건과 같도 록 넣은 후 포장에서 건조하고 매일 오후 5 시에 건물중을 측정하였다.

건조된 시료에 대한 조단백질 분석은 Kjeldahl 법(Tecator, Kjeltec Auto Sampler System 1035 Analyzer)을 사용하여 AOAC법(1990)으로 분 석하였다. $\mathrm{NDF}$ (neutral detergent fiber) 및 $\mathrm{ADF}$ (acid detergent fiber)는 Goering 및 Van Soest 방법(1970)으로 분석하였다. RFV(relative feed value)의 산출은 $\mathrm{ADF}$ 와 $\mathrm{NDF}$ 가 건물소화율 및 섭취량과 높은 상관관계를 가진다는 점에 근거하여 $\mathrm{ADF}$ 와 $\mathrm{NDF}$ 분석치에 의한 계산식 으로 산출하였다(Holland 등, 1990).

통계처리는 SAS(1999) package(ver. 6.12) 을 이용하여 분산분석을 실시하였으며, 처 리평균간 비교는 최소유의차(LSD)를 이용하 였다. 


\section{III 결과 및 고찰}

\section{1. 기후, 수확시 생육특성 및 건물수량}

우리나라의 천안지역에서 최근 5년간 기후 를 보면 Fig. 1에서 보는 바와 같다. 먼저 강 우량은 6월부터 9월에 전체 강우량의 $75 \%$ 가 집중되었으며, 특히 7 월과 8월에 $52.2 \%$ 로 전 체강우량의 절반이 내렸다. 반면 5월은 4월 보다 강우량이 적었다. 일사량은 4월, 5월 및 10 월이 다른 시기보다 높았다. 따라서 증발량은 5월이 가장 높았다. 서 등(2001)과 Smith 및 Brown(1994)도 양질의 건초를 제조하기 위해 서는 건초제조 기간에 맑은 날씨와 강우가 중요하다고 하여 기상조건의 중요성을 지적 하였다. 특히, 건초수확, 제조 및 저장 중 강 우는 건초의 호흡 연장, 양분용탈, 잎 탈락 및 호기성 미생물의 증식에 영향을 미친다고 하였다(Baylor, 1991). 따라서 우리나라에서는 건초를 제조할 경우 강우량은 적고 증발량과 일사량이 많은 5월이 건초조제에 적합한 시 기라고 할 수 있다.

일년생 콩과목초의 생육특성 및 건물수량 은 Table 1 에서 보는 바와 같다. 콩과목초의 개화일은 bolta balansa clover가 4월 22일로 가장 먼저 개화하였으며, 다음은 crimson clover로 5 월 1 일에 개화하였다. 그러나 persian clover는 수확시까지 개화를 하지 않았다. 따라 서 일년생 콩과목초를 수확한 시기의 생육단계
는 crimson clover는 개화초기, bolta balansa clover는 개화후기, persian clover는 영양생장 후기였다. 김 등(2002)의 시험에서도 crimson clover는 5월 10 일 이전에 개화 하였으나 persian clover는 5월 10 일 이전에는 개화를 하지 않은 것으로 보고 되었다.

수확시 건물률은 Table 1 에서 보는 바와 같 이 crimson clover가 24.7\%로 가장 높았으며, 수 확시까지 출수를 하지 않은 persian clover는 $18.8 \%$ 로 건물률이 가장 낮았다 $(\mathrm{P}<0.05)$. 그러 나 persian clover는 berseem clover와 같이 줄기 가 비어 있는 특성으로 인해 건초제조시 줄기 와 잎이 같은 속도로 건조되어 고품질의 건초 를 제조할 수 있을 것으로 생각된다.

건물수량은 crimson clover와 $3,242 \mathrm{~kg} / \mathrm{ha}$ 로 가 장 많았으며, bolta balansa 및 persian clover는 각각 2,592 및 $2,022 \mathrm{~kg} / \mathrm{ha}$ 이었다.

Fig. 1. Precipitation, evaporation and sunshine at Cheonan, 1999 to 2003.

Table 1. Agronomic characteristics and dry matter yield of annual legumes at Cheonan, 2000 to 2001

\begin{tabular}{lclcc}
\hline Species & Flower date & Growth stage & Dry matter & DM yield \\
\hline \hline & $\ldots$ Date $\cdots$ & & $\ldots \% \cdots$ & $\cdots \mathrm{kg} / \mathrm{ha} \cdots$ \\
Crimson clover & 1 May & Early bloom & 24.7 & 3,242 \\
Bolta balansa & 22 April & Late bloom & 20.4 & 2,592 \\
Persian clover & - & Late vegetative & 18.8 & 2,022 \\
\hline $\operatorname{Mean}$ & & & 21.3 & 2,619 \\
$\operatorname{LSD}(0.05)$ & & 1.57 & $\mathrm{NS}$ \\
\hline
\end{tabular}




\section{2. 잎과 줄기의 함량 및 건조속도}

수확시 일년생 콩과목초의 잎과 줄기의 함 량은 Fig. 2에서 보는 바와 같다. 잎에서는 crimson, bolta balansa 및 persian clover가 각각 18.7, 17.9 및 29.8\%로 persian clover가 가장 높다. 김 등(1999)의 시험에서는 crimson clover가 alfalfa 및 red clover보다 높았으나, 본 시험에서는 비교한 초종이 상이하며, persian clover가 crimson보다 높아 건초의 품질이 높 을 가능성이 있었다.

콩과목초의 포장건조시 수분 함량의 일중변 화는 Fig. 3에서 보는 바와 같다. 콩과목초가 건초조제에 적합한 수분 함량 $20 \%$ 까지 도 달하는 데 공시초종 모두 4 일이 소요되었다. 초종간 비교에서는 수분 함량은 crimson, bolta balansa 및 persian clover가 건조전에는 각각 75.3, 79.6 및 $81.2 \%$ 였으나 건조 후에는 각각 5.4, 5.2 및 3.3\%로 persian clover의 수분 함량 이 크게 감소하였다. 이는 persian clover가 다 른 초종에 비하여 잎이 많고, 줄기가 비어있 어 건조에 유리한 것으로 생각된다.

반전횟수에 따른 수분 함량의 변화에서는 초종에서와 같이 개시후 4 일간에는 급격한 수분감소를 보였으나, 5일 이후에는 완만한 감소를 보였다. 그러나 반전횟수간의 수분 함량의 차이는 나타내지 않았다. 한 및 김 (1996)에서는 1일 3회 반전이 1 회 반전에 비

Fig. 2. Leaf and stem ratios based on dry weight of annual legumes at harvest.
Fig. 3. Effect of species and tedding frequency on the changes of moisture content of annual legumes during field curing.

해 수분 함량 감소에 효과가 있다고 하였으나 본 시험에서는 초종간의 차이보다 적었다. 이는 한 및 김(1996) 시험이 초종이 연맥이 고 가을에 시험을 수행한 반면 본 시험은 상 대적으로 수량이 적은 일년생 콩과목초를 봄 에 건초 제조하였기 때문으로 생각된다.

김 등(1999)의 시험에서는 수분 함량이 $20 \%$ 에 도달하는데 7 일이 소요된다고 하였으 나 본 시험에서는 4일이 소요되어 3 길 단 축되었다. 이는 시험에 이용한 초종의 차이 보다는 수확시 수분 함량이 본 시험이 낮은 것이 원인으로 여겨진다. 그리고 건조 기간 중에 날씨도 함께 영향을 미친 것으로 판단 된다. 
Table 2. Effect of species and tedding frequency on crude protein(CP), neutral detergent fiber (NDF), acid detergent fiber(ADF), and relative feed value(RFV) of annual legumes during field curing

\begin{tabular}{|c|c|c|c|c|c|}
\hline Species & Tedding frequency & CP & NDF & $\mathrm{ADF}$ & RFV \\
\hline & - Time - & (n........ & .......... o & M $\cdots \cdots \cdots$ & (........ \\
\hline & 1 & 15.6 & 44.7 & 39.1 & 122 \\
\hline \multirow[t]{3}{*}{ Crimson } & 2 & 14.8 & 45.1 & 40.5 & 118 \\
\hline & 3 & 14.1 & 43.4 & 39.7 & 124 \\
\hline & 1 & 17.5 & 41.4 & 33.7 & 141 \\
\hline \multirow[t]{3}{*}{ Bolta balansa } & 2 & 17.1 & 41.1 & 34.1 & 141 \\
\hline & 3 & 16.9 & 43.2 & 35.6 & 132 \\
\hline & 1 & 20.9 & 33.3 & 29.7 & 184 \\
\hline \multirow[t]{2}{*}{ Persian } & 2 & 19.4 & 33.1 & 29.4 & 186 \\
\hline & 3 & 18.2 & 37.1 & 29.8 & 165 \\
\hline \multicolumn{6}{|l|}{ Mean of species } \\
\hline Crimson & & 14.8 & 44.4 & 39.7 & 122 \\
\hline Bolta balansa & & 17.5 & 41.9 & 34.4 & 138 \\
\hline Persian & & 19.5 & 34.5 & 29.6 & 178 \\
\hline \multicolumn{6}{|c|}{ Mean of tedding frequency } \\
\hline 1 & & 18.0 & 39.8 & 34.1 & 149 \\
\hline 2 & & 17.1 & 39.8 & 34.6 & 148 \\
\hline 3 & & 16.8 & 41.2 & 35.0 & 140 \\
\hline \multicolumn{6}{|l|}{ Provability } \\
\hline \multicolumn{2}{|l|}{ Species(S) } & 0.0001 & 0.0001 & 0.0001 & 0.0001 \\
\hline \multicolumn{2}{|c|}{ Tedding frequency(T) } & 0.0243 & 0.0169 & 0.2399 & 0.0026 \\
\hline \multicolumn{2}{|c|}{$\mathrm{S} \times \mathrm{T}$} & 0.6223 & 0.0023 & 0.3065 & 0.0021 \\
\hline
\end{tabular}

\section{3. 건초의 품질}

콩과목초의 초종과 반전횟수에 따른 콩과 목초의 품질은 Table 2에서 보는 바와 같다. 먼저 조단백질 함량은 숙기가 늦은 persian clover가 $19.5 \%$ 로 가장 높았으며, bolta balansa clover는 $17.5 \%$ 로 다음으로 높았다. 한편 crimson clover는 $14.8 \%$ 로 공시초종 중에서 가장 낮았다. 김 등(1999)의 시험에서는 crimson clover의 조단백질 함량이 red clover와 알팔파보 다 낮았으며, 김 등(2002)의 시험에서는 persian clover는 공시초종 중에서 조단백질 함량이 높아 본 시험과 같은 경향이었다.
한편 반전횟수에 따른 비교에서는 횟수를 증가함에 따라 단백질 함량이 $18.0 \%$ 에서 $16.8 \%$ 로 감소였으나 초종간 차이보다 적었 다. 한 및 김(1996)의 시험에서도 품종간 질 소함량의 차이가 있었으나 반전횟수간 차이 는 없다고 하여 본 시험과 비슷하였다.

$\mathrm{NDF}$ 및 $\mathrm{ADF}$ 함량은 crimson clover가 44.4 및 $39.7 \%$ 로 공시초종 중에서 가장 높았으며, persian clover는 34.5 및 29.6\%로 가장 낮아 품질이 우수한 것으로 평가되었다. $\mathrm{ADF}$ 와 $\mathrm{NDF}$ 함량을 근거로 추정 계산한 상대사료가 치(RFV)는 persian clover가 178이었으며, crimson 및 bolta balansa clover는 각각 122 및 
138 이었다.

반전횟수에 따른 $\mathrm{NDF}$ 및 $\mathrm{ADF}$ 함량에서 는 3 회가 1 회와 2 회보다 높았다. 건초의 상 대사료 가치도 1 회에서 3회로 반전횟수를 증가함에 따라 149 에서 140 으로 감소하였으 나, 1회와 2회는 차이가 없었다. 그러나 본 시험의 일변생 콩과목초의 상대사료가치는 미국의 사초등급(AFGC)에 의하면 공시품종 모두가 1 등급 이상으로 우수하였다(Balyor, 1991).

일년생 콩과목초의 생초 및 건초의 조단백 질 함량은 Fig. 4에서 보는 바와 같다. 먼저 초종간의 비교에서는 persian clover의 생초 및 건초의 조단백질 함량이 21.9 및 19.5\%로 $2.4 \%$ 감소하였으나 crimson 및 bolta balansa clover가 각각 1.1 및 $1.2 \%$ 감소하여 persian clover의 조단백질 감소가 컸다. 이는 persian clover가 다른 초종에 비하여 잎의 함량이 많 아 탈엽에 의한 단백질의 감소가 많은 것으 로 생각된다. 한편 반전횟수에 따른 생초와
건초의 조단백질 함량은 생초는 $18.8 \%$ 에 비 하여 반전 1회, 2회 및 3회는 각각 18.0, 17.1 및 $16.8 \%$ 로 반전을 많이 함에 따라 단백질의 감소가 많았다. 김 등(1999) 및 Collins(1990) 는 생초와 건초의 조단백질 비교에서 건초가 생초 보다 $4.6 \%$ 와 $12.0 \%$ 낮았다고 하여 본 시험보다 다소 많은 단백질의 손실이 있었다. 이는 건조 기간이 원인으로 김 등(1999)은 건조기간이 7일 이 소요된 반면 본 시험은 4 일이 소요되어 건 초 조제시 용탈에 의한 단백질의 손실이 적은 것으로 생각된다.

생초와 건초의 상대사료가치(RFV)는 Fig. 5 에서 보는 바와 같이 초종간의 비교에서는 crimson 및 bolta balansa clover는 10 및 11이 감소하였으나 persian clover는 변화가 없었다. 생초와 건초의 상대사료가치는 조단백질과 다 른 양상으로 이는 persian clover의 줄기가 비워 있고 잎의 함량이 많아 세포벽물질(cellulose, hemicellulose 및 lignin)이 적었던 것에 기인한 것으로 여겨진다. 일년생 콩과목초는 반전횟수
Fig. 4. Loss in crude protein of annual legumes during field curing.
Fig. 5. Loss in relative feed value of annual legumes during field curing. 
에 의해서도 상대사료가치의 감소가 있었으며, 특히 3 회가 1 회 및 2회보다 감소의 폭이 컸다.

이상의 결과를 종합해 볼 때 일년생 콩과 목초를 우리나라에서 5월 중순에 수확하여 건조를 제조할 경우 포장건조기간은 4 일이 소요되었으며, persian clover가 건조에 의한 수분 감소가 빨랐다. 조단백질, $\mathrm{NDF}, \mathrm{ADF}$ 및 $\mathrm{RFV}$ 를 비교해 볼 때에도 persian clover가 다른 초종보다 품질이 우수하였다. 이는 persian clover가 다른 초종에 비하여 수확시 숙 기가 늦고, 식물체 부위중 잎의 함량이 많으 며 줄기가 비워있는 것이 원인으로 생각된 다. 그리고 crimson 및 bolta balansa clover의 사초품질등급도 1 등급 이상으로 우리나라에 서 봄철에 고품질의 건조를 생산할 수 있었 다. 건초의 반전횟수에 있어서는 1 회와 2회 는 큰 차이가 없었으나 3회 반전은 품질의 감소가 많았다. 따라서 농가에서 포장건조시 반전횟수는 2회 이하로 하는 것을 권장하고 자 한다.

\section{IV 요 약}

우리나라에서는 봄철에 일년생 콩과목초를 수확한 후 포장건조시 목초의 품질에 관한 연 구는 거의 없는 실정이다. 따라서 본 시험은 일년생 콩과목초인 crimson clover(Trifolium incarnatum L.), bolta balansa clover(Trifolium balanansae L.) 및 persian clover(Trifolium resupinatum L.)를 봄에 건조하였을 때 건초 의 품질에 관한 정보를 얻기 위하여 수행하 였다. 일년생 콩과목초의 수확시 건물률은 crimson clover가 24.7\%로 가장 높았고, bolta balansa 및 persian clover는 각각 20.4 및 18.8\% 였다. 콩과목초의 포장 건조후 수분 함량은 persian clover가 가장 낮았으며, 수분함량 20\% 도달시간은 공시초종 모두 4 일이 소요되었 다. 반전횟수는 건초의 수분 함량에 영향을 미치지 않았으며, 포장건조 기간중 변화 양 상은 비슷하였다. Persian clover의 건물당 잎 과 줄기의 비는 crimson 및 bolta balansa clover보다 높았다. 조단백질 함량도 잎이 많 은 persian clover가 19.5\%로 다른 초종보다 높았다. 포장 건조중 반전횟수를 증가함에 따라 조단백질 함량은 $17.8 \%$ 에서 $16.5 \%$ 로 감소하였다. Persian clover의 NDF 및 $\mathrm{ADF}$ 함량은 다른 일년생 콩과목초보다 낮았다. 반전횟수에 따른 비교에서는 3회 반전의 $\mathrm{NDF}$ 및 $\mathrm{ADF}$ 함량이 1회 및 2회 반전보다 높았다. Persian clover의 상대사료가치(RFV) 는 178 로 가장 높았으며, 이는 건초품질등급 의 최상급에 해당된다. Crimson 및 bolta balansa clover의 RFV도 1 등급으로 고품질의 건초였다. 반전횟수에 의한 상대사료가치는 반전횟수를 증가함에 따라 150 에서 140 으로 감소하였다. 이상의 연구결과를 볼 때 persian clover가 식물체 부위중 잎이 많고, 줄기가 비워있고 다른 초종보다 숙기가 늦어, 일년 생 콩과목초 중에서 건초 품질이 우수하였 다. 그리고 포장건조시 품질손실이 적은 콩 과목초를 생산하기 위해서는 반전횟수를 2회 이하로 하여야 한다.

\section{$\mathrm{V}$ 인 용 문 헌}

1. AOAC. 1990. Official Method of Analysis(15th ed.). Association of Official Analytical Chemists. Washington, D. C.

2. Baylor, J. E. 1991. Hay management in North America. In Field guide for hay and silage management. Bolsen, K. K., J. E. Baylor, and M. E. McCullough. 1991. National Feed Ingredients Association.

3. Collins, M. 1983. Wetting and maturity effects on the quality of legume hay. Agron, J. 75:523-527.

4. Goering, H. L. and Van Soest, P. J. 1970. Forage Fiber Analysis. Agr. Handbook No. 379. USDA.

5. Holland, C., Kezar, W., Kautz, W. P., Lazowski, E. J., Mahanna, W. C. and Reinhart, R. 1990. The pioneer forage manual-A nutritional guide. Pioneer Hi-Bred Int. Inc., Des Moines, IA.

6. Pitt, R. E., Muck, R. E. and Pickering, N. B. 1991. A model of aerobic fungal growth in silage. 2. Aerobic stability. Grass and Forage Sci. 46:30-312.

7. Rotz, C. A. and Abrams, S. M. 1987. Alfalfa 
losses and quality changes during hay harvest and storage. Trans. ASAE 31:350-355.

8. SAS Institute, Inc. 1999. SAS user's guide : Statistics. SAS Inst., Inc., Cary, NC.

9. Smith, D. M. and Brown, D. M. 1994. Rainfallinduced leaching and leaf losses from drying alfalfa forage. Agron. J. 86:503-510.

10. 김동암, 김원호. 1993. 추파사료작물이 사일리지 용 옥수수의 생장, 수량 및 사료가치에 미치는 영향. 한초지 13(2):122-131.

11. 김동암, 김종덕, 이광녕, 신동은, 정재록, 김원호. 1997. 콩과목초 잔주의 사일리지용 옥수수에 대 한 질소공급 효과. 한초지 17(3):293-304.

12. 김동암, 김종덕, 한건준, 이광녕, 김종근. 1999. 봄철 포장건조 콩과목초의 수량 및 품질 손실. 한초지 19(2):127-132.
13. 김종덕, 권찬호, 김수곤, 박형수, 고한종, 김동암. 2002. 중부지방에서 일년생 콩과목초의 사초생산 성 비교. 동물자원지 44(5):617-624.

14. 서성, 김종근, 정의수, 이종경, 김원호, 신동은. 2001. 건조방법별 알팔파와 봄연맥의 건초조제 효과. 한초지 21(2):67-74.

15. 이재용. 2003. 조사료(수입조사료)의 정책방안. In 수입조사료의 유통 현황 및 개선방안. 한국초지 학회, (사)한국단미사료협회.

16. 한건준, 김동암. 1996. 품종 및 반전횟수가 추계 수확 연맥건초의 사료가치에 미치는 영향. 한초 지 16(2):169-176.

(접수일자 : 2004. 3. 11. / 채택일자 : 2004. 5. 3.) 